\title{
In vitro evaluation of fungicides and organic extracts against Macrophomina phaseolina (Tassi) Goid. isolated from pigeonpea [Cajanus cajan (L.) Millsp.]
}

D.M. Pathak* and R.R. Patel

Department of Plant Pathology, College of Agriculture, Navsari Agricultural University,Campus Bharuch, Maktampur (Gujarat) India

\section{ARITCLE INFO}

Received : 08.08 .2019

Revised : 07.09.2019

Accepted : 21.09 .2019

KEY WORDS :

Fungicides, Pigeonpea, Organic extracts

*Corresponding author:

Email : dmpathak@nau.in

\section{ABSTRACT}

Ten fungicides at three different concentrations were screened in vitro by poisoned food technique for evaluating their efficacy against $M$. phaseolina, in which mancozeb (dithane M-45, 75\% WP), carbendanzim (bavistin, 50\% WP), carbendanzim + mancozeb (sixer, 75\%WP) and metalexyl 18\% + mancozeb 64\% (ridomil, 75\% WP) were proved to be highly toxic to the growth of the M. phaseolina. Eight different organic extracts were tested against $M$. phaseolina by poisoned food technique with different concentration in vitro. All the extracts were inhibitory to $M$. phaseolina significantly lower mycelium growth was recorded in Neem cake followed by coconut. Next best were FYM, mustard cake, sesamum cake and vermicompost. While lowest inhibition of mycelial growth of M. phaseolina was observed in groundnut cake and castor cake.

How to view point the article : Pathak, D.M. and Patel, R.R. (2019). In vitro evaluation of fungicides and organic extracts against Macrophomina phaseolina (Tassi) Goid. isolated from pigeonpea [Cajanus cajan (L.) Millsp.]. Internat. J. Plant Protec., 12(2) : 147-151, DOI : 10.15740/HAS/IJPP/12.2/147-151, Copyright@ 2019: Hind Agri-Horticultural Society. 